\title{
The effect of a caseinate hydrolysate on cytokine release and RNA expression in TNF- $\alpha$ stressed 3T3-L1 adipocytes
}

\author{
S.M. O’Sullivan'1, Y.C. O’Callaghan ${ }^{1}$, M.B. O’Keeffe ${ }^{2}$, R.J. FitzGerald ${ }^{2}$ and N.M. O’Brien ${ }^{1}$ \\ ${ }^{1}$ School of Food and Nutritional Sciences, University College Cork, Ireland and ${ }^{2}$ Department of Life Sciences, \\ University of Limerick, Ireland
}

Obesity and diabetes are linked to chronic inflammation and elevated pro-inflammatory cytokine release ${ }^{1}$. The use of antiinflammatory agents to reduce this inflammation may help to prevent or alleviate these conditions ${ }^{2}$. Bioactive peptides with various physiological functions, including anti-inflammatory activity, have been isolated from bovine casein following hydrolysis by plant, mammalian and microbial-derived proteinases. The objective of this study was to determine the effect of intact caseinate, a caseinate hydrolysate and their simulated gastrointestinal digests (SGID) on cytokine production and RNA expression in Tumour Necrosis Factor- $\alpha(\mathrm{TNF}-\alpha)$ stressed adipocytes.

A $5 \mathrm{kDa}$ permeate of a Flavourzyme ${ }^{\circledR}$ hydrolysate of sodium caseinate was generated at laboratory scale. The unhydrolysed caseinate $(\mathrm{UH})$ and the $5 \mathrm{kDa}$ permeate of the hydrolysate $(\mathrm{H})$ were subjected to SGID. Pre-adipocytes (3T3-L1) were differentiated to adipocytes over three weeks in media containing $1 \mu \mathrm{g} / \mathrm{ml}$ insulin, $0 \cdot 25 \mu \mathrm{M}$ dexamethasone, $0 \cdot 5 \mathrm{mM}$ 3-isobutyl-1-methyxanthine (IBMX) and $2 \mu \mathrm{M}$ rosiglitazone. After differentiation, adipocytes were pre-treated with test samples at $0.05 \%$ (w/v) for 24 hours, following which stress was induced using TNF- $\alpha$ for 24 hours. The production of pro-inflammatory cytokines; Interleukin (IL)- 6 and Monocyte Chemotactic Protein-1 (MCP-1) along with the anti-inflammatory adipokine: adiponectin, were then measured using ELISA. The RNA expression of IL-6 was also measured using quantitative RT-PCR. Data was expressed as a percentage of the TNF- $\alpha$ stressed control.

\begin{tabular}{|c|c|c|c|c|c|c|c|c|}
\hline & \multicolumn{2}{|c|}{$\begin{array}{l}\text { Adiponectin Cytokine } \\
\text { production }(\% \text { Control) }\end{array}$} & \multicolumn{2}{|c|}{$\begin{array}{l}\text { MCP-1 Cytokine } \\
\text { production ( } \% \text { Control) }\end{array}$} & \multicolumn{2}{|c|}{$\begin{array}{l}\text { Interleukin-6 Cytokine } \\
\text { production ( } \% \text { Control) }\end{array}$} & \multicolumn{2}{|c|}{$\begin{array}{l}\text { Interleukin-6 RNA } \\
\text { expression ( } \% \text { Control) }\end{array}$} \\
\hline & Mean & $\mathrm{SD}$ & Mean & $\mathrm{SD}$ & Mean & SD & Mean & SD \\
\hline Control & $100 \cdot 0$ & 1.0 & $100 \cdot 0$ & $8 \cdot 0$ & $100 \cdot 0$ & $0 \cdot 9$ & $100 \cdot 0$ & $35 \cdot 8$ \\
\hline UH & 96.4 & $2 \cdot 4$ & $116 \cdot 8$ & $8 \cdot 0$ & $267 \cdot 8^{*}$ & $16 \cdot 1$ & $1706 \cdot 9 *$ & 84.9 \\
\hline $\mathrm{UH}_{\mathrm{SGID}}$ & $98 \cdot 6$ & $2 \cdot 8$ & $115 \cdot 1$ & 4.9 & $260 \cdot 0 *$ & 5.9 & $1987.7 *$ & $19 \cdot 5$ \\
\hline $\mathrm{H}$ & 95.9 & $0 \cdot 2$ & 99.9 & $7 \cdot 7$ & $108 \cdot 9$ & $14 \cdot 8$ & $44 \cdot 7$ & 28.6 \\
\hline $\mathrm{H}_{\text {SGID }}$ & $98 \cdot 5$ & $3 \cdot 3$ & 108.9 & $7 \cdot 4$ & $142 \cdot 2 *$ & $10 \cdot 4$ & $68 \cdot 1$ & 57.5 \\
\hline
\end{tabular}

UH: Unhydrolysed Casein, H: Hydrolysate. Values are means of two independent experiments. Statistical analysis was by ANOVA followed by Dunnett's test. $* P<0.05$

IL-6 production and RNA expression were significantly $(\mathrm{P}<0.05)$ increased by UH and $\mathrm{UH}_{\mathrm{SGID}}$ compared to control. The hydrolysate $(\mathrm{H})$ did not significantly change IL-6 production. $\mathrm{H}_{\text {SGID }}$ produced a significant increase in IL-6 production although RNA expression was not affected. None of the samples produced significant changes in MCP-1 or adiponectin production. In conclusion, UH and $\mathrm{UH}_{\mathrm{SGID}}$ appear to have a pro-inflammatory effect on cytokine release in adipocytes. Enzymatic hydrolysis of caseinate using Flavourzyme $^{\circledR}$ appears to decrease this effect.

Funding for this research was provided under the National Development Plan, through the Food Institutional Research Measure, administered by the Department of Agriculture, Food and the Marine, Ireland.

1. Calder PC, Ahluwalia N, Brouns F, et al. (2011) Br J Nutr 106, Suppl 3:S5-78.

2. Esser N, Paquot N, Scheen AJ (2015) Expert Opin Investig Drugs 24, Suppl 3:283-307. 